\title{
Civil Servants' View of the Development of e-Government in Slovenia
}

UDK: $35(497.4): 004.9: 659.2$

\section{Tina Jukić}

University of Ljubljana, Faculty of Administration tina.jukic@fu.uni-lj.si

\section{Mateja Kunstelj}

University of Ljubljana, Faculty of Administration mateja.kunstelj @fu.uni-lj.si

\section{Mitja Dečman}

University of Ljubljana, Faculty of Administration mitja.decman @fu.uni-lj.si

\section{Mirko Vintar}

University of Ljubljana, Faculty of Administration mirko.vintar@fu.uni-lj.si

\begin{abstract}
The paper presents the results of a study focused on the so-called internal aspect of e-government - $i$. e., the aspect of the civil servants. It is wellknown that in both Slovenia and most other countries there is a significant discrepancy between the selection and the actual use of the possibilities that e-government provides. A substantial number of researchers have been intensely engaged in the study of factors inciting (mainly) the citizens to use e-government. In our belief, those factors need also be searched for within the internal e-government users, i.e. the civil servants. In this perspective, we have examined: (1) their use of, and satisfaction with, information technologies in the job context; (2) their skills required for e-government; (3) the effect of e-government on their job, their organisation, and public administration in general; (4) their views of further development of e-government within the public administration. A number of results indicate that responsibility for the low use of e-government by citizens and enterprises can in fact be partly ascribed to the civil servants. Further, the research has revealed that the surveyed civil servants lacked sufficient skills required for an active participation in the development of e-government, and that this development has not resulted in any vital changes in the operations of the public administration.
\end{abstract}

Key words: electronic administration, e-government, civil cervants, public administration, Slovenia. 
Jukić, Kunstelj, Dečman, Vintar

Civil Servants' View of the Development of

e-Government in Slovenia

\section{Introduction}

The development of electronic operations or administration ("business") within the public administration, which popularly has widely come to be simply called "e-government," has for several years been the focus of attention of various interest groups and research fields. Externally, this development has in practice mainly meant a rapid development of electronic services for various user groups, particularly citizens and enterprises. And internally, it has meant an increasing prevalence of non-paper communication among different administrative bodies and various public databases, registers and cadastres, on which the development of modern electronic civil service administration is based.

However, despite the apparently brisk and successful development, we cannot be entirely satisfied with the achievements. In initial years, governments across the world and in Slovenia had mainly focused on a rapid development of the selection of services without also seriously considering their effects, the potential users, their interests and expectations. At the beginning, this trend was taken up by research which primarily focused on analysing the selection of services, and the metrics and evaluation of the level of its development. Only in the past two or three years did those trends begin to undergo change, as it was becoming increasingly clear that in many aspects development was going in the wrong direction, and that in determining priorities and guidelines for further development, it was the users, their needs, expectations and benefits that needed to be considered as paramount. It was after 2004 that the first empirical studies appeared in Europe focusing on investigating the users' expectations and satisfaction with e-government. Generally, those studies mainly defined as users the external users, i.e. primarily citizens and enterprises, which somewhat reduces the value of their results.

As far as we know, the first significantly comprehensive and extensive European study of the users' satisfaction with e-government and their expectations as to its further development was conducted in Slovenia within the Institute for Informatization of Administration, Faculty of Administration, in 20052006. This study is so much more relevant because it also focused - in addition to the traditional user groups covered by similar research studies, such as citizens and enterprises - on the internal users, i.e. the civil servants who, according to our assumptions, play a major role in the promotion and spread of the use of e-government. 


\section{Jukić, Kunstelj, Dečman, Vintar \\ Civil Servants' View of the Development of e-Government in Slovenia}

Due to the extensiveness of the study, whose results can be examined in greater detail at the Institute for Informatization of Administration's web page (see Vintar et al., 2006a, 2006b, 2006c), the present paper only presents a lesser part of it, i.e. the part that focused on the civil servants as internal egovernment users. Within it, we were primarily testing the following three hypotheses:

Hypothesis 1: Civil servants are partly responsible for the low use of e-government services by external users (citizens and enterprises).

Hypothesis 2: Civil servants lack sufficient skills required for an active participation in the development of e-government.

Hypothesis 3: The development of e-government has not resulted in any vital changes in internal operations of the public administration.

The following chapter presents details of the methodology used in the implementation of empirical research. The third chapter describes the results of certain similar, although not entirely comparable, studies mainly conducted across Europe, while in Chapter 4 we compiled the most important results of the presented part of our study, and in Chapter 5 tried to evaluate them.

\section{Methodological framework}

The survey was conducted through the use of questionnaires distributed by e-mail in January 2006. The basis for the sampling frame was all the employees (with their own e-mail address) in the Slovenian state-level administrative bodies and municipalities. The survey implementation phases were the following. First, all the:

- state secretaries at the ministries,

- heads of the bodies within ministries (both their central and regional units),

- heads of administrative units (i.e., local offices of central government),

- heads of municipal administrations or the municipal secretaries (where there was no head person) or the mayors (where no other data were available)

- were mailed a formal letter informing them

- that we were going to conduct a survey of civil servants via a questionnaire that would be submitted to the organisation's central e-mail address, and 
Jukić, Kunstelj, Dečman, Vintar

Civil Servants' View of the Development of

e-Government in Slovenia

- that we were asking the administrator of that central e-mail address to forward the questionnaire to all full-time staff with their own e-mail address, and to inform us:

- how many full-time employees there were in their organisation,

- to how many addresses they have forwarded the questionnaire.

Given that only a sample of the organisations had provided us with the information indicated in the last subparagraph, we were unable to use those data for further analysis. Therefore we retrieved data on the sampling frame size from the ISPO e-government IT data service ${ }^{1}$, or its section incorporating the number of full-time employees in state administration as of 1 July 2005. We excluded from the sampling frame the police, the armed forces, the Protocol Service of the Republic of Slovenia, and the Slovenian Intelligence and Security Agency, while including into it all the municipalities. Being unable to procure the data on the number of employees in the latter, we used in the calculations the average of 10 employees per a municipality. This resulted in a sampling frame of the size of 19,563 civil servants (Table 1).

Table 1: Sampling frame and the number of responses

\begin{tabular}{|c|c|c|c|c|}
\hline Type of organ & $\begin{array}{l}\text { Number of } \\
\text { employees }\end{array}$ & $\begin{array}{c}\% \text { of } \\
\text { employees }\end{array}$ & $\begin{array}{c}\text { Number of } \\
\text { received } \\
\text { responses }\end{array}$ & $\begin{array}{l}\% \text { of received } \\
\text { responses }\end{array}$ \\
\hline Government agencies & 1251 & $6 \%$ & 97 & $5,3 \%$ \\
\hline Core ministries & 4583 & $23 \%$ & 134 & $7,4 \%$ \\
\hline Bodies within ministries & 8865 & $45 \%$ & 808 & $44,4 \%$ \\
\hline Administrative units & 2934 & $15 \%$ & 506 & $27,8 \%$ \\
\hline $\begin{array}{l}\text { Municipalities - up to } \\
10.000 \text { residents }\end{array}$ & 1390 & $7 \%$ & 76 & $4,2 \%$ \\
\hline $\begin{array}{l}\text { Municipalities - up to } \\
20.000 \text { residents }\end{array}$ & 370 & $2 \%$ & 87 & $4,8 \%$ \\
\hline $\begin{array}{l}\text { Municipalities - above } \\
20.000 \text { residents }\end{array}$ & 170 & $1 \%$ & 93 & $5,1 \%$ \\
\hline Missing data & - & - & 17 &, $9 \%$ \\
\hline Total & 19563 & $100 \%$ & 1818 & $100 \%$ \\
\hline
\end{tabular}

On 7 January 2006 we e-mailed the survey questionnaires to the central e-mail addresses of the state administration bodies and the municipalities. We

1 http://e-uprava.gov.si/ispo/ 
received 1818 responses in five weeks (Table 1). This being a large enough and random, i.e. representative, sample, we may, taking into account the standard estimation error and a 95\% confidence interval, generalise the results calculated based on the entire sample, or the entire selection of responses. If we were to make the sample representative by the respective categories of organisations (i.e. stratums), the shares of responses would need to coincide with the shares of employees; this would only be feasible if we got hold of an exhaustive list of e-addresses of all the employees in public administration, which at the time we were unable to do. In what follows we briefly present the demographic structure of the surveyed municipal and state government employees. Among the 1818 responses we had received, nearly one-half were from the bodies within the ministries, $28 \%$ from the administrative units, and $14 \%$ from the municipalities (Figure 1). The rest came from the employees of government agencies and core ministries.

Over one-half of the respondents had worked in public administration for 11 years or more; a similar percentage were over 39 years old, meaning that they had already had a relatively high amount of experience with public administration operation. As concerns their educational structure (Figure 1), 68\% had completed post-secondary college or undergraduate university studies, followed by the graduates of secondary vocational and high schools (24\%), while 7\% held a Masters, specialisation, or PhD. Over one-half of the respondents held the position of an official, one-quarter were members of support staff, and the rest belonged to the organisation's management (Figure 1).

Figure 1: Shares of respondents by level of education (left) and by type of position (right) $(n=1818)$

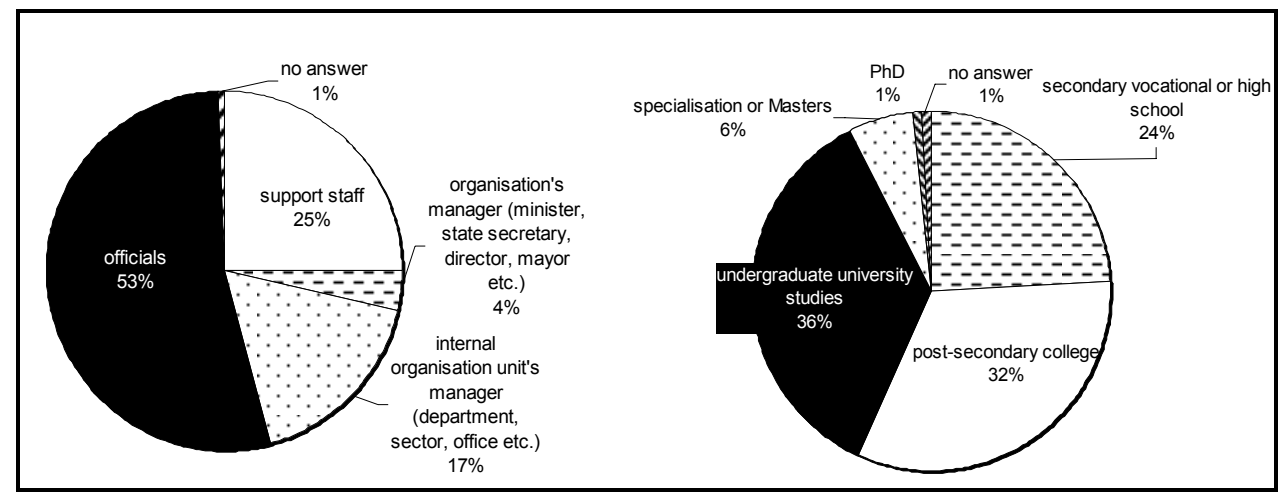


Jukić, Kunstelj, Dečman, Vintar

Civil Servants' View of the Development of

e-Government in Slovenia

In addition to the questions asking the respondents to provide the basic data about themselves, the survey questionnaire consisted of a succession of the following four question groups:

- Group 1: questions about the use of, and satisfaction with, information technologies in the job context;

- Group 2: questions about the existent and desired skills required for e-government;

- Group 3: questions about the effect of e-government on the job, the organisation, and public administration in general;

- Group 4: questions about future trends in the development of egovernment within public administration.

The questionnaire was designed as a form in an Excel document, set and protected so that the respondents were able to fill it in, save it, and e-mail it to the appropriate address easily and correctly. This in turn enabled a simple compilation of a database of responses, followed by a statistical analysis of it in the SPSS programme package.

The present paper only presents the most interesting results in addition to those needed to confirm or reject the proposed hypotheses. More detailed results are available in Vintar et al. (2006a, 2006b, 2006c).

\section{Existent research}

This chapter presents an overview of certain studies that (at least indirectly or partly) were concerned with the development and implementation of e-government in the public administration environment as perceived by civil servants, or the so-called internal e-government users.

Thus, an extensive study was conducted within the project of "Breaking the barriers to e-government," focusing on the barriers to the development of e-government (Oxford Internet Institute, 2006). Results were provided by 996 respondents from over 60 countries (with 73\% of them coming from the EU). $58 \%$ of the respondents worked in the public sector, and $49 \%$ also participated in the development and implementation of e-government.

The respondents were expected to provide information on the importance of particular barriers in the development of e-government. To this end, they were presented with 30 identified barriers clustered into nine groups: resistance, 


\section{Jukić, Kunstelj, Dečman, Vintar \\ Civil Servants' View of the Development of e-Government in Slovenia}

technical barriers, take up, administrative barriers, privacy, design, legal barriers, costs, accessibility. Three barriers in particular seem to be paramount according to the results: (1) coordination among the central, regional, and local levels of government; (2) resistance to change by government officials; and (3) lack of interoperability of IT systems.

Also interesting is the study called "Organisational Changes, Skills and the Role of Leadership required by eGovernment," conducted among those in charge of the public administration in the EU countries (EIPA, 2005). Responses were procured from 19 Member States and Bulgaria, which at the time was an acceding country. The survey focused on the organisational changes, skills and leadership vital in implementing e-government and transforming public services. The results indicate that in most countries that the respondents come from, e-government action plans incorporate measures pertaining to skills, organisational changes and leadership, while over one-half of the countries also employ special instruments for identifying insufficient skills. Among them, Denmark sticks out as particularly interesting, as it has recently began to use two new tools: "competence barometer" and "competence game" (EIPA, 2005, p. 24, 27-28; see also ILO, 2007). The main findings of the study are the following (EIPA, 2005, p. 59-60):

- organisational changes caused by the implementation and development of e-government have been gradual rather than radical;

- different skills and competences that the development of egovernment requires need to be identified and defined; ICT skills are non-problematic, while more stress should be placed on planning and management, skills in the field of interpersonal relations, and social and communication skills;

- the managers must ensure that the decisions taken reflect the organisation's specific needs in line with its long-term strategy; they must also ensure that the skills and human resources are developed to an appropriate level.

Internal e-government users were also dealt with by a study conducted in the UK (Jones and Williams, 2005). Its results are reason for concern, as they indicate that the public servants are insufficiently involved in the implementation of the ICT; no less than $39 \%$ distrusted the management's decisions relating to the ICT, $32 \%$ had not been given the chance to express their views concerning the ICT in their work, and $29 \%$ had not been consulted by anyone with respect to the implementation of the IT. No less than two-thirds of the servants 
Jukić, Kunstelj, Dečman, Vintar

Civil Servants' View of the Development of

e-Government in Slovenia

had not participated in the decision-making concerning the implementation of the technologies, which is - as the study has also found - a serious problem. The (public) managers were no less critical; $28 \%$ thought that their staff's IT skills needed to improve, only $16 \%$ maintained that their organisation provided its staff with excellent IT training courses, only $27 \%$ were confident that the staff were able to effectively use the ICT, and only $29 \%$ consulted their staff with respect to the ways in which ICT are used at work (Jones and Williams, 2005, p. 23-25). The study includes some recommendations, such as the following (Jones and Williams, 2005, p. 38-39):

- ICT-related decision-making processes must involve all those who would use those technologies, particularly when this would affect their day-to-day work;

- the question must be asked of what would the effects of ICT-related projects be (e.g. what is it that the citizens need and expect);

- project management skills are indispensable;

- the purpose of technology cannot simply be a "digitalisation « of existent processes, but rather it needs to be considered how they could be changed;

- the departments within an organisation, as well as their processes, need to be linked to each other;

- staff need to be trained and educated;

- a two-way communication with the servants needs to be ensured; it must be clear how they perceive the changes.

Opinions of senior civil servants about the development of e-government were also researched by a study conducted in the USA (Hart-Teeter, 2003). It was found that e-government had (already) become an integral part of American governance, although nearly one-half of the respondents (44\%) thought that the lack of financial resources was an obstacle on the path to egovernment (Hart-Teeter, 2003, p. 22, 24). Anyhow, 82\% of them believed that e-government had a highly (36\%) or partly $(46 \%)$ positive effect on the way that government operates, while an even higher share of "optimists" was recorded concerning the effects to be expected in the following 5-10 years (Hart-Teeter, 2003, p. 24-25). As concerns further development of egovernment, more than one-half $(56 \%)$ thought it was necessary to expedite the spread of the Internet for the communication between the citizens and the administrative bodies on grounds that e-government provided possibilities for 


\section{Jukić, Kunstelj, Dečman, Vintar \\ Civil Servants' View of the Development of e-Government in Slovenia}

better services, communication and efficiency, while 35\% were in favour of a slower development of it on grounds that many citizens lacked access to the Internet, in addition to which they saw unresolved issues concerning the security and privacy of such operations (Hart-Teeter, 2003, p. 27).

\section{Research results}

This chapter presents the research results grouped into four subchapters:

- the use of, and satisfaction with, information technologies in the job context;

- skills required for e-government;

- the effect of e-government on the job, the organisation, and public administration in general;

- views of further development of e-government within public administration.

\subsection{The use of, and satisfaction with, information technologies in the job context}

As the survey was conducted via e-mail, the questionnaire only included the civil servants using personal computers and e-mail, but the error due to the non-inclusion of non-users is certainly not significant. Thus we may conclude that all respondents use personal computers and electronic mail, while Internet is used by $95 \%$ of them (Figure 2). A large majority use the said IT in their work every day: the computer $99 \%$, electronic mail $93 \%$, and Internet $72 \%$.

Digital certificates, being frequently used today for both remote access to application programmes or web services and user identification and digital signing, are only used by $26 \%$ of the respondents (Figure 2), while $5 \%$ of them plan to start using them.

Further, the results indicate that practically all the surveyed employees (97\%) use the basic computer solutions or application programmes such as Word, Excel and similar, and a majority of them (77\%) also use specialised computer solutions such as documents management applications (e.g. SPIS), accounting applications (e.g. MFERAC), and applications facilitating the implementation of work processes (Figure 2). 
Jukić, Kunstelj, Dečman, Vintar

Civil Servants' View of the Development of

e-Government in Slovenia

Figure 2: Use of information technologies in the work of the surveyed civil servants $(n=1818)$

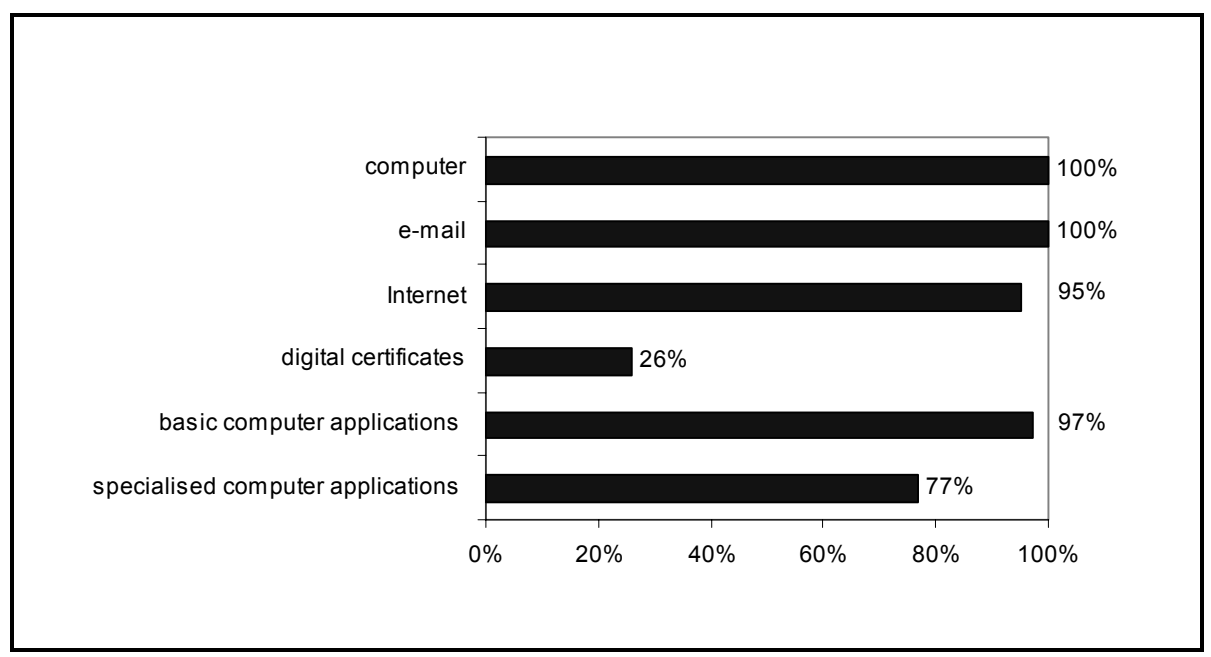

All respondents were also asked to assess within a 1-5 scale ${ }^{2}$ how well they are provided in their job with hardware and software with regard to the needs of their work. On average, the respondents are less than satisfied in this case - the average value of responses being 3.91.

The respondents also answered questions about their knowledge and use of the state web portal e-Government. It seems that $12 \%$ of the surveyed civil servants are not acquainted with this portal. Among those who know it, the majority use it at least once a week (41\% of those asked or $36 \%$ of all respondents), followed by those using it at least once a month (23\% of those asked or $20 \%$ of all respondents), while $8 \%$ of those who know it (i.e., $7 \%$ of all respondents) have so far never used it. Those not knowing the portal were additionally asked how much interest they had to start using it. Disappointingly, the majority (56\%) expressed little interest, 38\% were keen to start using it, while $6 \%$ expressed no interest at all.

We also examined how satisfied the civil servants were with the process of implementing e-government in their job context, their organisation, and the public administration in general. The results indicate (Figure 3, Table 2) that they are the most satisfied with the process of implementing e-government in their job context (the mean value of responses being 3.77), and the least satisfied with this process in the public administration in general (the mean value of re-

21 - very badly, 5 - very well 
sponses being 3.64), while the satisfaction with this process in their organisation was on average estimated at 3.70.

Figure 3: The surveyed civil servants' satisfaction with the process of implementing e-government in their job context, in their organisation, and in public administration in general $(n=1818)$

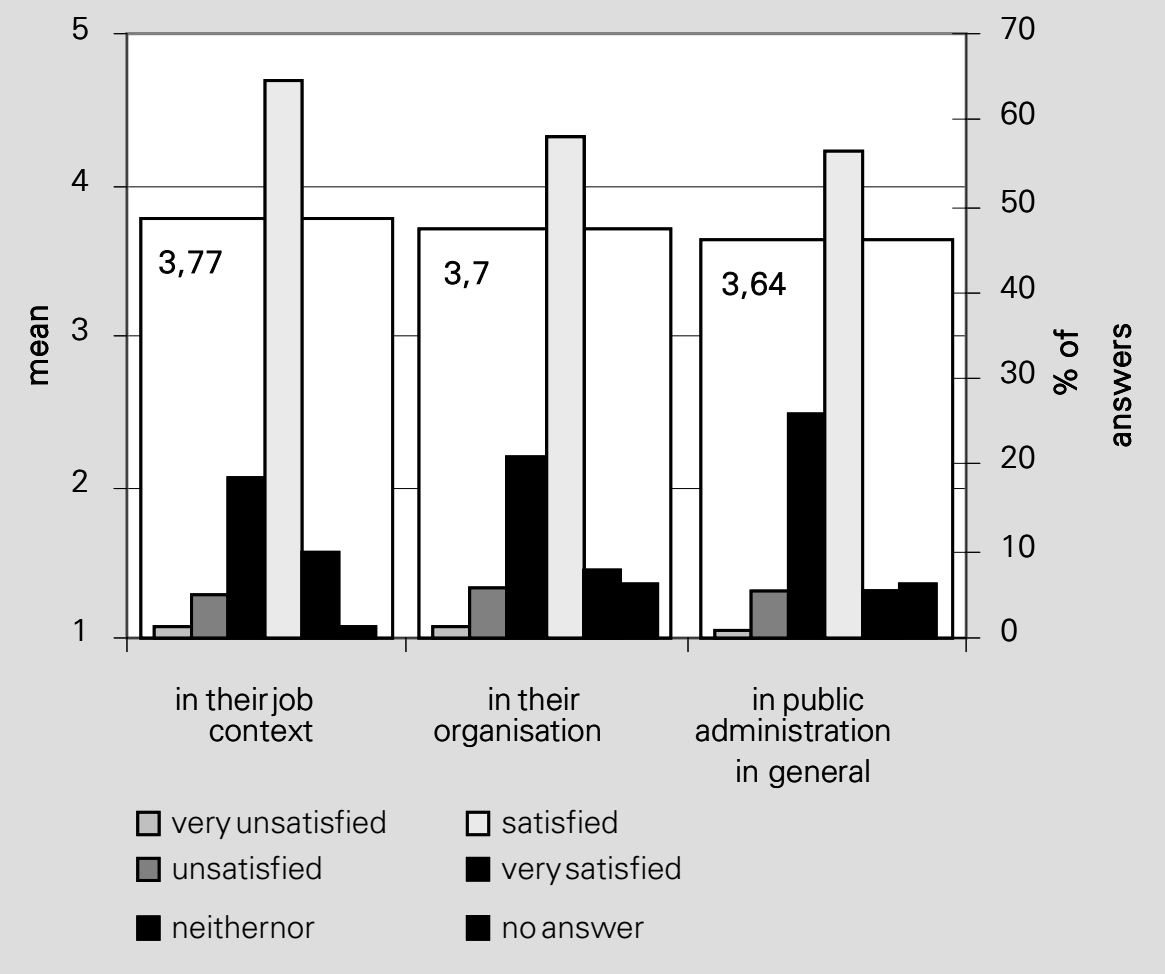

We also inquired about trust that civil servants have in doing business in the public administration electronically. The results indicate (Table 2) that most of them (64\%) do trust in such administration, while there are also many who are less trustful, which is reflected in the mean value of responses $\left(3.72^{3}\right)$.

31 - not at all, 2 - no, 3 - neither nor, $4-I$ do, 5 - very much 
Jukić, Kunstelj, Dečman, Vintar

Civil Servants' View of the Development of

e-Government in Slovenia

Table 2: The surveyed civil servants' trust in doing business in the public administration electronically - left $(n=1818)$, and their satisfaction with the process of implementing e-government - right $(n=1818)$

\begin{tabular}{|c|c|c|c|c|c|c|c|c|}
\hline \multirow{2}{*}{\multicolumn{3}{|c|}{ Trust in e-government }} & \multicolumn{6}{|c|}{ Satisfaction with e-government implementation } \\
\hline & & & \multicolumn{2}{|c|}{ in the job context } & \multicolumn{2}{|c|}{ in their organisation } & \multicolumn{2}{|c|}{ in PA in general } \\
\hline & $n$ & $\%$ & $n$ & $\%$ & $\mathrm{n}$ & $\%$ & $\mathrm{n}$ & $\%$ \\
\hline not at all & 7 & 4 & 25 & 1,4 & 19 & 1,0 & 16 & 9 \\
\hline no & 104 & 5,7 & 87 & 4,8 & 108 & 5,9 & 94 & 5,2 \\
\hline neither nor & 388 & 21,3 & 334 & 18,4 & 381 & 21,0 & 468 & 25,7 \\
\hline I do & 1.154 & 63,5 & 1.174 & 64,6 & 1.055 & 58,0 & 1.027 & 56,5 \\
\hline very much & 117 & 6,4 & 178 & 9,8 & 143 & 7,9 & 97 & 5,3 \\
\hline no answer & 48 & 2,6 & 20 & 1,1 & 112 & 6,2 & 116 & 6,4 \\
\hline average & & & & & & & & \\
\hline
\end{tabular}

\subsection{Skills required for e-government}

In this context, the respondents were asked to assess within a 1-5 scale:

- the level of their skill and competence in computering and information technologies;

- their knowledge of different ways in which e-government can be used by themselves as civil service employees;

- their knowledge of different ways in which e-government can be used by their clients (citizens, enterprises).

The results indicate (Table 3) that the surveyed civil servants best assessed their skill and competence in computering and information technologies (the mean value of responses being 3.65), followed by knowledge of different ways in which e-government can be used by civil servants (3.42), while the 
worst assessment was given to the knowledge of different ways in which egovernment can be used by their clients (3.16).

Table 3: Assessments of the level of the respondents' skill and competence in computering and information technologies, and of their knowledge of different ways in which e-government can be used by civil service employees and their clients $(n=1818)$

\begin{tabular}{|c|c|c|c|c|c|c|}
\hline & \multicolumn{2}{|c|}{$\begin{array}{l}\text { level of skill and } \\
\text { competence in } \\
\text { computering and IT }\end{array}$} & \multicolumn{2}{|c|}{$\begin{array}{l}\text { familiarity with e- } \\
\text { government possibilities } \\
\text { for public servants }\end{array}$} & \multicolumn{2}{|c|}{$\begin{array}{c}\text { familiarity with e- } \\
\text { government possibilities } \\
\text { offered to customers } \\
\text { outside PA }\end{array}$} \\
\hline & $\mathrm{n}$ & $\%$ & $n$ & $\%$ & $n$ & $\%$ \\
\hline very bad & 9 &, 5 & 22 & 1,2 & 55 & 3,0 \\
\hline bad & 127 & 7,0 & 191 & 10,5 & 354 & 19,5 \\
\hline neither nor & 485 & 26,7 & 632 & 34,8 & 658 & 36,2 \\
\hline good & 1.021 & 56,2 & 851 & 46,8 & 625 & 34,4 \\
\hline very good & 146 & 8,0 & 65 & 3,6 & 62 & 3,4 \\
\hline no answer & 30 & 1,7 & 57 & 3,1 & 64 & 3,5 \\
\hline average & & & & & & \\
\hline
\end{tabular}

We also desired to be told where the respondents had acquired their IT skills, providing them with answers from which they could choose more than one (Table 4). The results indicate that they the least frequently acquired their IT skills within training courses paid for by themselves (5.9\%) and within regular education (30\%), and the most frequently by self-training $(63 \%)$ and within the courses organised by the organisation that employs them (45\%). Those who replied that they had gained skills within organised courses were additionally asked how long the training had lasted. An analysis indicates (Table 4) that those trainings mainly lasted up to two weeks $(68 \%)$. 
Jukić, Kunstelj, Dečman, Vintar

Civil Servants' View of the Development of

e-Government in Slovenia

Table 4: Forms in which the surveyed civil servants acquired their IT skills (left, $n=1818$ ), and the total duration of organised additional trainings (right, $n=1269$ )

\begin{tabular}{|lcc|}
\hline & $n$ & $\%$ \\
\hline within regular education & 537 & 29,5 \\
\hline self-training & 1.141 & 62,8 \\
\hline training courses paid for by themselves & 108 & 5,9 \\
\hline $\begin{array}{l}\text { within the courses organised in the organisation that } \\
\text { employs them }\end{array}$ & 700 & 38,5 \\
\hline $\begin{array}{l}\text { within the courses organised by the organisation that } \\
\text { employs them }\end{array}$ & 823 & 45,3 \\
\hline no answer & 20 & 1,1 \\
\hline
\end{tabular}

\begin{tabular}{|lll|}
\hline no. of weeks & $n$ & $\%$ \\
\hline less than 1 & 409 & 32,2 \\
\hline from 1 to 2 & 449 & 35,4 \\
\hline from 2 to 5 & 277 & 21,8 \\
\hline more than 5 & 109 & 8,6 \\
\hline no answer & 25 & 2,0 \\
\hline
\end{tabular}

We also wanted to find out in which fields the civil servants would need additional IT skills. The respondents were allowed to choose several answers. It seems (Table 5) that the most needed skills were those related with the use of various specialised application programmes and e-services (57\%), and the functioning and use of databases (45\%). Training in the use of Excel also ranks highly, coming third (35\%).

Table 5: Fields in which the surveyed civil servants would need additional IT skills $(n=1818)$

\begin{tabular}{|lcc|}
\hline & $n$ & $\%$ \\
\hline the use of various specialised application programmes and e-services & 1043 & 57,4 \\
\hline functioning and use of databases & 819 & 45,0 \\
\hline usage of electronic spread-sheets (eg. Excel) & 640 & 35,2 \\
\hline planning and building of information systems & 393 & 21,6 \\
\hline process management and process organisation & 391 & 21,5 \\
\hline Internet usage & 342 & 18,8 \\
\hline basic ICT knowledge & 326 & 17,9 \\
\hline e-mail usage & 267 & 14,7 \\
\hline usage of word processor (eg. Word) & 226 & 12,4 \\
\hline web technologies, secure e-business, digital signature & 6 & 0,3 \\
\hline Power Point presentations & 4 & 0,2 \\
\hline foreign language & 2 & 0,1 \\
\hline no answer & 130 & 7,2 \\
\hline
\end{tabular}


Jukić, Kunstelj, Dečman, Vintar

Civil Servants' View of the Development of e-Government in Slovenia

\subsection{The effect of e-government on the job, the organisation, and public administration in general}

The next group of questions referred to an estimation of the effects that the implementation of e-government has had. The questions were of the closed type, and formulated so that in spite of descriptive answers, the lower value always represented a worse condition, e.g. the time needed to perform a task is: 1-significantly longer; 2-longer; 3-unchanged; 4-shorter; 5-significantly shorter (Figure 4). The changes ranked by the respondents as the most "negative" include greater range of tasks (the mean value of responses being 2.69), greater work load (2.74), and more demanding work (2.85) (Figure 4). Among the positive experiences, the one sticking out is less time required to perform a task and greater transparency of operations (3.84), followed by smoother dealings with the civil servants working outside the respondents' organisation (3.77), and a higher quality of the services for the clients both within and outside the civil service (3.75).

Figure 4: Levels of changes produced by the implementation of e-government in the surveyed civil servants' job context $(n=1818)$

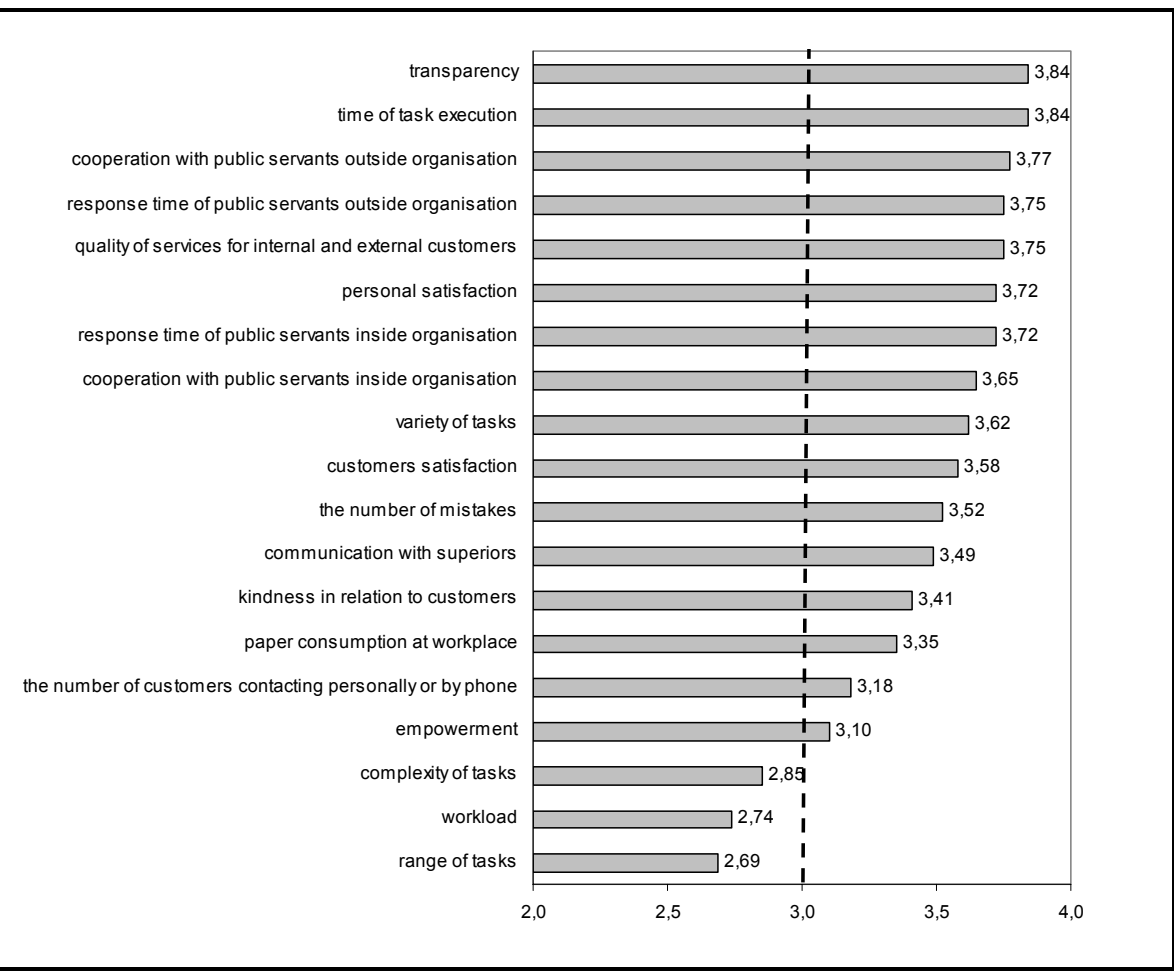


Jukić, Kunstelj, Dečman, Vintar

Civil Servants' View of the Development of

e-Government in Slovenia

We were also interested in the general effect that the use of egovernment has had so far. Although most respondents judge (Table 6) that this effect on their job, their organisation, and public administration in general has been positive, there is also a significant share of them who are not entirely sure about this (the mean value of all responses being $3.87^{4}$ ). The effect estimated as the least positive is that on the job (3.85), followed by the effect on the organisation (3.87), and that on the public administration in general (3.89) (Table 6).

Table 6: Assessments of the general effect that the use of e-government has so far had on the respondents' job, their organisation, and public administration in general $(\mathbf{n}=1818)$

\begin{tabular}{|c|c|c|c|c|c|c|}
\hline & \multicolumn{2}{|c|}{ on the job } & \multicolumn{2}{|c|}{ on their organisation } & \multicolumn{2}{|c|}{ on the PA in general } \\
\hline & $\mathrm{n}$ & $\%$ & $\mathrm{n}$ & $\%$ & $\mathrm{n}$ & $\%$ \\
\hline very negative & 3 & 0,2 & & & & \\
\hline negative & 15 & 0,8 & 8 & 0,4 & 4 & 0,2 \\
\hline neither nor & 407 & 22,4 & 362 & 19,9 & 353 & 19,4 \\
\hline positive & 1.162 & 63,9 & 1.208 & 66,4 & 1.189 & 65,4 \\
\hline very positive & 174 & 9,6 & 153 & 8,4 & 166 & 9,1 \\
\hline no answer & 57 & 3,1 & 87 & 4,8 & 106 & 5,8 \\
\hline average & \multicolumn{2}{|c|}{3,85} & \multicolumn{2}{|c|}{3,87} & \multicolumn{2}{|c|}{3,89} \\
\hline
\end{tabular}

We also desired to learn whether civil servants call the attention of their clients to the ways in which they can use e-government. The results indicate (Table 7 ) that most of them (55\%) do so occasionally, while only $26 \%$ do so regularly.

Table 7: The civil servants' calling of the clients' attention to the ways in which they can use e-government $(n=1818)$

\begin{tabular}{|lcc|}
\hline & $\mathrm{n}$ & $\%$ \\
\hline yes, always & 479 & 26,3 \\
\hline yes, sometimes & 1002 & 55,1 \\
\hline no, never & 265 & 14,6 \\
\hline no answer & 72 & 4,0 \\
\hline
\end{tabular}

41 - very negative, 2 - negative, 3 - neither nor, 4 - positive, 5 - very positive 
Jukić, Kunstelj, Dečman, Vintar

Civil Servants' View of the Development of e-Government in Slovenia

\subsection{Desired trends in the development of e-government}

With the purpose of learning from the surveyed civil servants their views of desired trends in the further development of e-government in Slovenian public administration, we (among other things ${ }^{\mathbf{5}}$ ) presented them with 12 possibilities of further development, asking them to assess their importance ${ }^{\mathbf{6}}$ (Figure 5). The respondents attributed the highest importance to trainings of civil servants (the average assessed importance being 4.47). The latter were followed by a shared use of public administration data (4.41), the implementation of common electronic administrative solutions and cooperation among the public administration bodies (4.36), and greater security of electronic operations in the public administration (4.35). Interestingly, the lowest average assessed importance (4.00) was attributed to a thorough reengineering of administrative procedures.

Figure 5: Assessed importance of different possibilities of further development of e-government $(n=1818)$

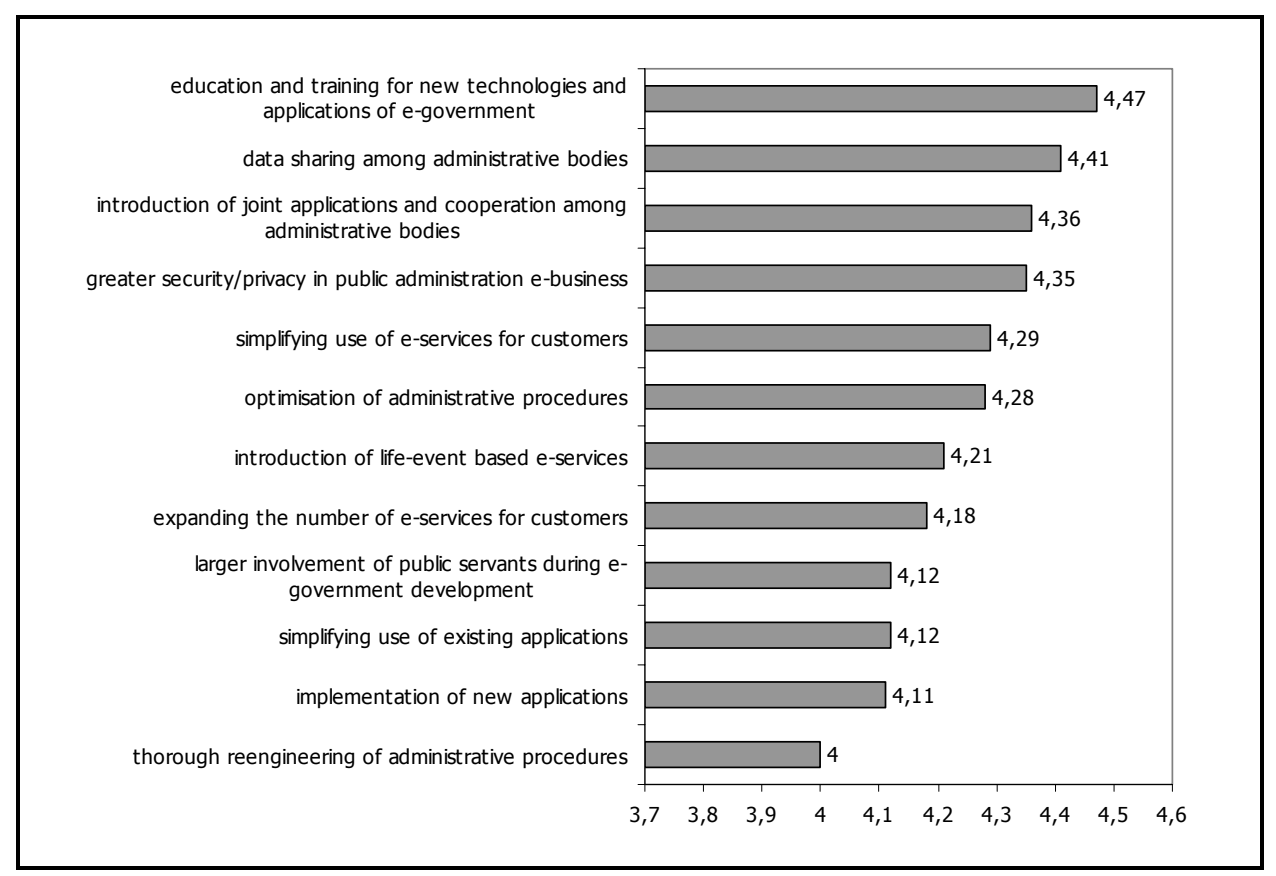

One of the questions referred to the challenges which according to the respondents' opinion their organisation will have to face in the development

5 More detailed results are available in Vintar et al. (2006a, 2006b, 2006c).

61 - totally unimportant, 2 - unimportant, 3 - neither nor, 4 - important, 5 - very important. 
Jukić, Kunstelj, Dečman, Vintar

Civil Servants' View of the Development of

e-Government in Slovenia

and implementation of e-government in the following five years. They were given a list of 11 possibilities with an additional one to write down their own opinion, among which they were supposed to choose maximally three possibilities ${ }^{7}$. Similarly as with the previous question (Figure 5), the challenge that comes first (being chosen by $48 \%$ of the respondents) is that of improving the civil servants' competences. It is followed by improving the information flow among the public administration bodies (43\%), and encouraging an innovative frame of mind within the organisation and including the employees in improving the ways in which operations are conducted (35\%). They, in turn, are followed by two approximately equally frequently chosen or assessed factors, i.e. improving the information flow within the organisation $(33 \%)$, and translating ideas into feasible services, processes and procedures (32\%) (Table 8).

Table 8: Factors which the respondents see as the greatest challenges that their organisation would have to face in the development and implementation of e-government in the following five years $(n=1818)$

\begin{tabular}{|lcc|}
\hline & $n$ & $\%$ \\
\hline improving public employee skills & 863 & 47,5 \\
\hline improving data sharing among public administration bodies & 787 & 43,3 \\
\hline $\begin{array}{l}\text { introducing an innovating approach to organizations and inclusion of } \\
\text { employees in improving the operating methods }\end{array}$ & 635 & 34,9 \\
\hline improving information flows inside organisations & 591 & 32,5 \\
\hline remoulding ideas into feasible services, processes and procedures & 577 & 31,7 \\
\hline introducing of efficient team-work & 501 & 27,6 \\
\hline assessing customers' need & 499 & 27,4 \\
\hline acquiring of financial resources & 489 & 26,9 \\
\hline introducing new services/processes & 426 & 23,4 \\
\hline mastering of changes-related fear & 380 & 20,9 \\
\hline acquiring of leadership's support for introducing changes & 269 & 14,8 \\
\hline no answer & 71 & 3,9 \\
\hline other & 20 & 1,1 \\
\hline
\end{tabular}

7 Analysis of the responses later revealed that a significant number of respondents chose more answers, some even all of them; in the statistical analysis, all were included in the calculations. 


\section{Discussion}

This chapter discusses the above presented research results and, in relation with them, the confirmation or rejection of the hypotheses presented in the introduction to this paper. The results are attempted to be compared with other, similar research studies presented at the beginning of the paper.

\subsection{Hypothesis I: Civil servants are partly responsible for the low use of e-government services by external users (citizens and enterprises)}

We have established with certainty that civil servants are partly responsible for the low use of e-government services by external users (citizens and enterprises), thus confirming our first hypothesis. This is indicated by a number of the results of our survey, while the fact sticking out most prominently is that $12 \%$ of the respondents are not even acquainted with the existence of the state web portal e-Government, which is the entry point to all Slovenian egovernment information and services, while $8 \%$ of those who do know it have so far never used it. Further, the results indicate that civil servants do not know well the different ways in which they (3.42) and their clients (3.16) can use e-government; even more - they know the latter significantly less well than the former. It is thus not really surprising that only $26 \%$ of the respondents regularly call the attention of their clients to the different ways in which they can use e-government. It is indeed surprising, though, that a high level of trust in electronic civil service administration is not prevalent among the civil servants (3.72), for which, however, they cannot entirely be themselves deemed responsible, as it is the management or the initiators of e-government projects who are responsible for awareness-raising regarding the new ways of operating, but still $-21 \%$ of the respondents belong to this group $17 \%$ are in charge of an internal organisational unit and $4 \%$ in charge of an organisation). It is interesting, however, that the respondents holding top positions trust somewhat more than other ones in e-government. It is obvious, then, that they do not spread this "climate" onto other employees. Also interesting, as well as reason for concern, is that it is the respondents from the local offices of central government ("administrative units") who trust the least in e-government (3.67), as it seems that administrative units have so far enjoyed preference in the implementation of e-government. 
Jukić, Kunstelj, Dečman, Vintar

Civil Servants' View of the Development of

e-Government in Slovenia

\subsection{Hypothesis II: Civil servants lack a sufficient amount of skills required for an active participation in the development of e-government}

It is also clear that the surveyed civil servants do not posses highly impressive skills required for an active participation in the development of egovernment. They themselves have not assessed the level of their skill and competence in computering and information technologies as good (3.65) and, as has already been mentioned above, they assessed as even worse their knowledge of different ways in which they (3.42) and their clients (3.16) can use e-government. Nevertheless, the respondents undoubtedly deserve praise, as they have acquired the majority of their IT skills by self-training (63\%). That there still remains a lot of room in the civil servants' acquiring of new skills is also indicated by the fact that it was precisely their training in the use of new technologies and e-government solutions that was judged as the most important (4.47) of the 12 listed factors of further development of egovernment. In addition, the respondents believe that improving the civil servants' competences is one of the most important challenges that their organisation will have to face in the development and implementation of $\mathrm{e}$ government in the following five years.

\subsection{Hypothesis III: The development of e-government has not resulted in any vital changes in internal operations of the civil service}

We may also find that the development of e-government has not resulted in any vital changes in internal operations of the public administration, and thus the third hypothesis is also confirmed. That is to say, according to the research results, there is still a great deal of room for improvements, as the average estimated value for none of the assessed effects or changes that the implementation of e-government had brought to the respondents' job exceeds the value of 4 . In addition, it seems that for the time being, if the surveyed civil servants are asked, we may not even expect any thoroughgoing changes and thus significant effects in the sense of effectiveness and efficiency of operations in the near future - that is to say, they deemed a thorough reengineering of administrative procedures in further development of e-government to be important $(4,00)$, but still the least important of the 12 possibilities listed. 


\subsection{Comparison with other research studies}

Because studies of internal e-government users (civil servants) are extremely rare (or at least rarely publicly published), and even those that do exist differ substantially according to the methodology employed, their results can only be compared with ours very "approximately," and with an appropriate measure of caution. Thus, the Oxford Internet Institute's study (2006) found resistance to change on the part of the civil servants as one of the main barriers to the development of e-government. Indirectly, our study reveals something similar; that is to say, as mentioned in the previous paragraph, the surveyed civil servants found a thorough reform of administrative procedures to be important for further development of e-government, but nevertheless the least important of the 12 possibilities listed - although it is vital in the devising of services that would suit the users (see Kunstelj, 2004).

The second study (EIPA, 2005) finds that organisational changes caused by the development and implementation of e-government in the EU have been gradual rather than radical. Generally speaking, we may say that our study implies something similar; among the 19 changes (resulting from the implementation of e-government in the job context) assessed by the respondents, none reached a mean value of 4,00 (the highest mean value being 3,84 ) - bearing in mind that a lower value always represented a worse condition. Further, the said study finds that skills in the field of information and communication technologies are non-problematic while greater stress should be placed on skills from the field of interpersonal relations, and social and communication skills. The latter undoubtedly also deserve a high level of attention, while it must not be overlooked that the respondents in our survey assessed their skill in computering and information technologies with a rather low mean value of 3.65, so that here also are many possibilities for improvement.

Further, Jones and Williams (2005) find in their study that two-thirds of the surveyed civil servants had not been involved in the decision-making related with the implementation of information technologies, while encouraging an innovative frame of mind and involving the employees in improving the operations are one of the most important factors that our respondents believe would be the biggest challenges in further development and implementation of e-government in the following five years.

It also seems that the lack of resources is a still existent challenge of the development of e-government. This was already pointed out by the surveyed 
Jukić, Kunstelj, Dečman, Vintar

Civil Servants' View of the Development of

e-Government in Slovenia

senior civil servants in a research study (Hart-Teeter, 2003), while $27 \%$ of our respondents felt that the acquiring of financial resources would be one of the challenges of further development and implementation of e-government.

\section{Conclusion}

We found in the paper that civil servants bear part of the responsibility for the low use of e-government services by external users (citizens and enterprises). However, as just said, only part of the responsibility can be attributed to them. Other reasons are to be sought in the still-too-low share of Internet users (approximately one-half of the citizens used it in 2007) as well as the fact that the existent e-government services do not bring a sufficient added value to the citizens (see also Kunstelj et al., 2007), due to which they still prefer to opt for the traditional ways of handling the matters with the public administration.

That more is needed for a success story about e-government than a mere provision of ever new services to be available at the World Wide Web has long been known. It seems, however, that the so-called internal users (civil servants) deserve and require equal, if not even greater attention than do their clients, or external users (citizens and enterprises). Promotion of egovernment is thus also needed within public administration, and so are, primarily, education and training in the use of new information and communication technologies, and motivation-raising and encouragement of the employees to participate in the development of new procedures, services and IT solutions supporting them. 


\section{Jukić, Kunstelj, Dečman, Vintar \\ Civil Servants' View of the Development of e-Government in Slovenia}

Tina Jukic graduated in 2005 at the Faculty of Administration, and completed her master's degree there in 2007. During this period she was already involved in research projects at the faculty. During her studies she received two faculty awards for special research achievements; in addition, she was the best student of the Master's Study Programme of Administration (level II). Currently she is a young researcher and an assistant for the studies in the field of informatics in public administration at the same faculty.

Mateja Kunstelj graduated in 1997, and received a Masters degree in 2002, from the Faculty of Computer and Information Science, University of Ljubljana. She works at the Faculty of Administration of the same university as Assistant for the studies in information technologies in public administration. In addition to teaching, she researches various aspects of e-government, its development and implementation. Currently her research activities mainly focus on the working out of a one-stop government framework and roadmap, the measurement and evaluation of e-government development, and the reengineering of administrative processes.

Mitja Dečman works as an assistant at the informatics department of University of Ljubljana, Faculty of Administration where he successfully supplements pedagogical activities with research and at the same time works or leads projects at the Faculty of Administration, on the Slovenian level or within European Union projects. The research covered software and hardware development within his graduate and Masters studies at Faculty of computer science, but is includes areas of informatics, information system development, e-government and in the last years within the area of security of e-business, digital signatures, long-term digital preservation and the aspects of authenticity.

Mirko Vintar is a full professor in informatics in public administration and e-government, vice-dean for scientific research, and head of the Research Centre and the Institute for Informatization of Administration at the Faculty of Administration, the University of Ljubljana. He gained his doctorate in IT and management studies at the Faculty of Economics, Ljubljana. For over 20 years his work has dealt with the informatization of public administration, with a major focus on the development of e-government in recent years. He is in charge of a series of domestic and international research and development-application projects in this field. He is a member of international scientific and specialist bodies involved in the research of this field (EGPA, Study Group on Informatisation of Public Administration, IFIP, WG 8.5, NISPAcee, WG on E-government). From 19932002 he was the chief and duty editor for the review Uporabna informatika (Applied IT). 
Jukić, Kunstelj, Dečman, Vintar

Civil Servants' View of the Development of

e-Government in Slovenia

\section{Bibliography}

- EIPA - European Institute of Public Administration (2005). „Organisational Changes, Skills and the Role of Leadership required by eGovernment: Survey for the 44th meeting of the Directors general responsible for Public Administration of the EU member states«, European Institute for Public Administration, Luxembourg, 2005.

- Hart-Teeter (2003). The New e-Government Equation: Ease, Engagement, Privacy and Protection. The Council for Excellence in Government, 2003.

- $\quad$ ILO - International Labour Organization (2007). „National Initiatives Concerning Human Resources Development by Social Partners - Denmark", http://www.ilo.org/public/english/employment/skills/hrdr/topic_n/t_56_dnk.htm, 27. 07. 2007.

- Jones, A., Williams, L. (2005). »How ICT? Managing at the frontline», The Work Foundation, London, 2005.

- Kunstelj, M. (2004). „Prenova procesov • predpogoj za uspešno uvedbo euprave«, XI. Dnevi slovenske uprave, Portorož, 23.-25. sep. 2004. Faculty of Administration, Ljubljana. http://www.iiu.si/.

- Kunstelj, M., Jukić, T., Vintar, M. (2007). "Analysing the demand side of egovernment : what can we learn from Slovenian users? «, Lect. notes comput. sci., 2007, p. 305-317.

- Oxford Internet Institute (2006). „Breaking Barriers to eGovernment: Overcoming Obstacles to Improving European Public Services: Online Survey of Barriers to eGovernment - Draft Report", www.egovbarriers.org/downloads/news/200612\%20survey\%20draft\%20report\% 20.doc, 02. 07. 2007.

- Vintar, M., Kunstelj, M., Dečman, M., Jukić, T., Drnovšek, D., Grošelj, B. (2006a). "Merjenje zadovoljstva uporabnikov e-uprave - Razširjeni povzetek", http://www.iiu.si/.

- Vintar, M., Kunstelj, M., Dečman, M., Jukić, T., Drnovšek, D., Grošelj, B. (2006b). "Merjenje zadovoljstva uporabnikov e-uprave : poročilo raziskave«, Ljubljana: Fakulteta za upravo, 2006.

- Vintar, M., Kunstelj, M., Dečman, M., Jukić, T., Drnovšek, D., Grošelj, B. (2006c). "Measuring E-government User Satisfaction • Extended summary", Ljubljana: Faculty of Administration, 2006. http://www.iiu.si/. 


\section{POVZETEK}

\section{POGLED JAVNIH USLUŽBENCEV NA RAZVOJ E-UPRAVE V SLOVENIJI}

$\checkmark$ prispevku predstavljamo rezultate raziskave, osredotočene na t.i. notranji vidik e-uprave - vidik javnih uslužbencev. Znano je, da obstaja med ponudbo in dejansko uporabo možnosti, ki jih ponuja e-uprava, tako $\checkmark$ Sloveniji kot tudi $v$ večini drugih držav, precejšen razkorak. Ne-malo raziskovalcev se intenzivno ukvarja s proučevanjem dejavnikov, ki vplivajo na odločitev (predvsem) občanov o uporabi e-uprave. Menimo, da je potrebno te dejavnike iskati tudi med notranjimi uporabniki e-uprave, torej javnimi uslužbenci. Pod drobnogled smo vzeli:

(1) uporabo in zadovoljstvo $z$ informacijsko tehnologijo na delovnem mestu;

(2) znanja, potrebna za e-poslovanje;

(3) vplive e-poslovanja na delovno mesto, organizacijo in upravo kot celoto;

(4) mnenja o nadaljnjem razvoju e-poslovanja v javni upravi.

Pri tem smo testirali tri hipoteze:

Hipoteza 1: Javni uslužbenci so delno odgovorni za nizko uporabo storitev e-uprave s strani zunanjih uporabnikov (občanov in podjetij).

Hipoteza 2: Javni uslužbenci nimajo dovolj znanj, potrebnih za aktivno sodelovanje pri razvoju e-uprave.

Hipoteza 3: Razvoj e-uprave ni povzročil bistvenih sprememb v notranjem poslovanju uprave.

Med 1818 prejetimi odgovori jih je bilo skoraj polovica iz organov $v$ sestavi ministrstev, $28 \%$ iz upravnih enot in $14 \%$ iz občin. Ostale odgovore smo prejeli od zaposlenih $v$ vladnih službah in ministrstvih. Več kot polovica anketirancev je $v$ javni upravi zaposlenih že 11 let ali več; podoben odstotek anketirancev je bil tudi starejši od 39 let, kar pomeni, da so imeli anketiranci že relativno veliko izkušenj s poslovanjem $v$ javni upravi. 
Jukić, Kunstelj, Dečman, Vintar

Civil Servants' View of the Development of

e-Government in Slovenia

Rezultati kažejo, da vsi anketiranci uporabljajo osebni računalnik in elektronsko pošto, internet pa uporablja $95 \%$ anketiranih javnih uslužbencev; praktično vsi anketirani javni uslužbenci uporabljajo osnovne računalniške rešitve oziroma aplikacije (97 \%) kot so Word, Excel ipd., večina (77 \%) pa tudi specializirane računalniške rešitve, kot so npr. aplikacije za vodenje dokumentarnega gradiva (npr. SPIS), računovodske aplikacije (npr. MFE$\mathrm{RAC}$ ) in aplikacije za pomoč pri izvajanju delovnih procesov. Digitalna potrdila uporablja le $26 \%$ anketirancev.

$\checkmark$ splošnem anketiranci niso (zelo) zadovoljni s tehnološko in programsko opremljenost svojih delovnih mest glede na potrebe, ki jih imajo pri delu - srednja vrednost odgovorov je 3,91.

Zanimivo, $12 \%$ anketiranih javnih uslužbencev ne pozna državnega spletnega portala e-Uprava. Med tistimi, ki ga poznajo, je največ takih, ki ga uporabljajo vsaj enkrat na teden ( $41 \%$ vprašanih), sledijo jim tisti, ki portal uporabljajo vsaj enkrat na mesec ( $23 \%$ vprašanih), $8 \%$ poznavalcev pa portala e-Uprava še nikoli ni uporabilo. Med tistimi, ki tega portala ne poznajo, jih je večina ( $56 \%$ ) izrazilo malo zanimanja za njegovo uporabo, $38 \%$ jih uporaba portala zelo zanima, $6 \%$ anketirancev pa za to ni izrazilo zanimanja.

Rezultati tudi kažejo, da anketiranci ne zaupajo najbolj v elektronski način poslovanja v javni upravi - srednja vrednost odgovorov je 3,72.

Kaže tudi, da je prostora za izboljšave dovolj tudi pri znanjih in usposobljenosti anketirancev na področju računalništva in informatike (srednja vrednost odgovorov je 3,65), kot tudi pri poznavanju možnosti, ki jih e-uprava nudi njim $(3,42)$ in njihovim strankam $(3,16)$.

Želeli smo tudi izvedeti, na katerih področjih bi javni uslužbenci potrebovali dodatna informacijska znanja. Anketiranci so lahko izbrali več odgovorov. Kaže, da anketirani javni uslužbenci najbolj potrebujejo znanja o uporabi različnih specializiranih aplikacij in e-storitev (57 \%) ter znanja o delovanju in uporabi zbirk podatkov (45\%). Na visoko tretje mesto se uvršča tudi izobraževanje s področja Excela (35\%).

Rezultati nadalje kažejo, da večina (anketiranih) javnih uslužbencev svojih strank ne opozarja redno na možnosti, ki jim jih nudi e-uprava - $55 \%$ jih to počne včasih, vedno pa le $26 \%$ anketiranih javnih uslužbencev.

Nadalje je moč ugotoviti, da večje spremembe, ki bi jih anketirani javni uslužbenci občutili na svojih delovnih mestih zaradi uvedbe e-poslovanja, še niso opazne (nobena od ocenjevanih sprememb ne presega 
vrednosti 4). Med najbolj "negativne« spremembe so anketiranci uvrstili večji obseg nalog (srednja vrednost odgovorov je 2,69), večjo obremenjenost $(2,74)$ in večjo zahtevnost izvajanja nalog (srednja vrednost odgovorov je 2,85). Med pozitivnimi izkušnjami izstopata krajši čas izvajanja nalog in večja preglednost poslovanja $(3,84)$, sledita pa mu boljše sodelovanje $z$ uslužbenci, s katerimi anketiranci sodelujejo izven svoje organizacije $(3,77)$ ter večja kakovost storitev za stranke znotraj ali izven uprave $(3,75)$.

Izmed 12 naštetih možnosti za nadaljnji razvoj elektronskega poslovanja $v$ upravi se anketirancem zdi najbolj pomembno izobraževanje javnih uslužbencev (povprečna ocena pomembnosti 4,47); sledijo skupna raba podatkov javne uprave $(4,41)$, uvedba skupnih elektronskih rešitev poslovanja in sodelovanje med organi javne uprave $(4,36)$ ter večja varnost e-poslovanja javne uprave $(4,35)$. Zanimivo je, da so najmanjšo povprečno oceno pomembnosti $(4,00)$ anketiranci namenili prenovi upravnih postopkov.

Brez dvoma lahko ugotovimo, da so javni uslužbenci delno odgovorni za nizko uporabo storitev e-uprave $s$ strani zunanjih uporabnikov (občanov in podjetij) ter tako potrdimo našo prvo hipotezo. To nakazujejo številni rezultati naše raziskave, $v$ prvi vrsti pa izstopa dejstvo, da $12 \%$ anketirancev sploh ne pozna državnega spletnega portala e-Uprava, ki predstavlja vstopno točko do vseh informacij in storitev e-uprave, med njegovimi poznavalci pa je $8 \%$ takih, ki tega portala še nikoli niso uporabili. Nadalje rezultati kažejo, da javni uslužbenci ne poznajo dobro možnosti, ki jih njim $(3,42)$ in njihovim strankam $(3,16)$ nudi e-uprava; še več - slednje so jim znane precej manj kot prve. Zato niti ne preseneča, da le $26 \%$ anketirancev svoje stranke redno opozarja na možnosti, ki jim jih nudi e-uprava. Preseneča pa, da med anketiranimi javnimi uslužbenci ne prevladuje visoka stopnja zaupanja $v$ elektronski način poslovanja $v$ javni upravi $(3,72)$, vendar jim za to ne moremo v celoti naprtiti odgovornosti, saj je osveščanje o novih načinih poslovanja $v$ pristojnosti vodij oziroma iniciatorjev projektov e-poslovanja, pa vendar - teh je med anketiranci $21 \%$ (17\% vodij notranjih organizacijskih enot ter $4 \%$ vodij organizacij). Zanimivo pa je, da anketiranci, ki zasedajo vodilna delovna mesta, $v$ e-poslovanje $v$ javni upravi zaupajo nekoliko bolj od ostalih anketirancev. Očitno torej te "klime" ne širijo na ostale zaposlene. Zanimivo in hkrati zaskrbljujoče je tudi, da anketiranci iz upravnih enot najmanj zaupajo $v$ elektronski način poslovanja $v$ javni upravi $(3,67)$; zdi se namreč, da so imele upravne enote pri dosedanjem uvajanju e-poslovanja prioriteto. 
Jukić, Kunstelj, Dečman, Vintar

Civil Servants' View of the Development of

e-Government in Slovenia

Prav tako je očitno, da anketirani javni uslužbenci nimajo zavidanja vrednih znanj, potrebnih za aktivno participacijo pri razvoju e-uprave. Ravni svojih znanj in usposobljenosti na področju računalništva in informatike sami niso ocenili kot dobre $(3,65)$, še slabše pa, kot že zgoraj omenjeno, so ocenili poznavanje možnosti, ki jih e-uprava ponuja njim $(3,42)$ in njihovim strankam $(3,16)$. Brez dvoma pa si anketiranci zaslužijo pohvalo, saj so večino svojih informacijskih znanj pridobili s samoizobraževanjem (63 \%). Da je na področju pridobivanja novih znanj javnih uslužbencev še veliko prostora, kaže tudi dejstvo, da so izmed 12-ih dejavnikov nadaljnjega razvoja e-uprave kot najpomembnejšega ocenili prav izobraževanje javnih uslužbencev za uporabo novih tehnologij in rešitev e-poslovanja $(4,47)$. Prav tako so anketiranci mnenja, da je izboljšanje usposobljenosti javnih uslužbencev eden najpomembnejših izzivov, s katerimi se bodo morale soočiti njihove organizacije pri razvoju in uvajanju e-poslovanja $v$ naslednjih petih letih.

Ugotoviti je tudi možno, da razvoj e-uprave ni povzročil bistvenih sprememb $\vee$ notranjem poslovanju uprave, tako potrjujemo tudi tretjo hipotezo. Prostora za izboljšave je namreč, sodeč po rezultatih raziskave, še zelo veliko, saj povprečne ocene nobenega od ocenjevanih vplivov oziroma sprememb, ki jih je prinesla uvedba e-poslovanja na delovna mesta anketirancev, ne presegajo vrednosti 4. Kaže pa tudi, da, če vprašamo anketirane javne uslužbence, nekih radikalnejših sprememb in $\mathrm{s}$ tem večjih učinkov $v$ smislu učinkovitosti in uspešnosti poslovanja tudi še ne gre pričakovati - temeljita prenova upravnih postopkov pri nadaljnem razvoju e-poslovanja $v$ upravi se jim je namreč zdela pomembna $(4,00)$, vendar izmed 12-ih naštetih možnosti najmanj pomembna. 